\title{
Haemoglobin Porto Alegre in a Cuban family
}

\author{
G. MARTÍNEZ, F. LiMA, M. WADE, M. ESTRADA, B. COLOMBO, \\ L. HEREDERO, AND H. GRANDA
}

From Instituto de Hematología e Inmunología, Apartado 8070, La Habana 8, and Departamento de Genética@ Médica, Instituto de Ciencias Básicas y Preclínicas Victoria de Girón, Universidad de La Habana, Cuba

SUMMARY During a screening programme for abnormal haemoglobins in Habana, one case of $\mathrm{Hb}^{\text {O }}$ Porto Alegre was found in 23000 cases analysed. The ability of this variant to polymerise in vitro and the absence of clinical features in the carriers have been confirmed. These observations are now $\vec{A}$ explained by the findings of high levels of glutathione in the red cells of subjects heterozygous for Hbं Porto Alegre: it is suggested that the increase of glutathione is responsible for the absence of in vivo polymerisation and accounts for the lack of clinical symptoms.

Haemoglobin Porto Alegre was first described in a Brazilian family (Tondo et al., 1963). Two more cases of this abnormal haemoglobin have been found in the same country (Seid-Akhaven et al., 1973) and one in Argentina (Peñalver et al., 1971; Peñalver and de Miani, 1972).

Haemoglobin Porto Alegre presents one extra thiol group in the $\beta$-chain due to substitution of the serine in position nine for cysteine (Bonaventura and Riggs, 1967). This haemoglobin has the ability to polymerise spontaneously in the haemolysate, while in vivo it is present in the tetrameric form, which accounts for the lack of anaemia, erythrocyte morphological abnormalities, and clinical symptoms (Tondo et al., 1963). The physicochemical properties of $\mathrm{Hb}$ Porto Alegre have been fully described (Tondo, 1972).

During the course of a screening for abnormal haemoglobins carried out on secondary school students of Havana City, one case of $\mathrm{Hb}$ Porto Alegre was found in 23000 cases analysed. We report here the study of the family carrying this abnormal haemoglobin.

\section{Subjects and methods}

Routine haematological data were obtained by standard methods (Dacie and Lewis, 1966). Red blood cells were counted in a TOA automatic cell counter (Microcell Counter, Model CC-1002). Electrophoresis was carried out in polyacrylamide (Heredero et al., 1974) and in starch gel (Smithies, 1959). Fetal haemoglobin was determined according Received for publication 19 August 1976 to the method of Betke (Betke et al., 1959) and $\mathrm{HbA}_{2}$ according to Bernini (Bernini, 1969). Haemoglobin purification was obtained by DEAE-Sephadex 3 chromatography (Jonxis and Huisman, 1968). Globin chain separation, aminoethylation, and trypsin digestion were carried out according to Clegg $(9$ et al. (1966). Fingerprints of the aminoethylated. abnormal $\beta$-chains were obtained as described Baglioni (1951). Amino acid analysis was performed in a Carlo Erba Aminoacid Analyzer (Mod. 3A 47).

G6PD activity was determined by the method described in the WHO Report (1967). 6PGD gluta- $\triangle$ thione peroxidase and glutathione reductase activity $\overrightarrow{\vec{P}}$ were determined as summarised in Yunis (1969). Glutathione levels were determined using the method of Beutler (1968).

\section{Results}

The index case was found because of the appearance on polyacrylamide gel electrophoresis at $p \mathrm{H} 8.6$ of a $\delta$ fresh haemolysate, of a large amount of a fast $₹$ moving band similar to $\mathrm{HbA}_{3}$. The case was ao healthy 16-year-old boy, with no previous medical history. Physical examination did not show anyo abnormalities and the haematological values were within the normal range. All the other members of his. family were studied: the father and 4 sibs were also N found to be heterozygous for the abnormal haemo-N globin. The pedigree is shown in Fig. 1 and the haematological data are summarised in Table 1.

Storage of the haemolysate at $-20^{\circ} \mathrm{C}$ for a few days produced a slowband migrating between $\mathrm{HbS}$ and $\mathrm{HbC}$ on starch gel electrophoresis at $p \mathrm{H} \mathrm{8.6} \mathrm{(Fig.} \mathrm{2).}$ 
Table 1 Haematological data of family

\begin{tabular}{|c|c|c|c|c|c|c|c|c|c|c|c|c|c|}
\hline $\begin{array}{l}\text { Family } \\
\text { members } \\
\text { and age } \\
(y)\end{array}$ & $\begin{array}{l}\text { Hb } \\
\text { type }\end{array}$ & $\begin{array}{l}H b \\
(g / d l)\end{array}$ & $\begin{array}{l}R B C \\
\times 10^{6} / \\
\mathrm{mm}^{3}\end{array}$ & $\begin{array}{l}P C V \\
\%\end{array}$ & $\begin{array}{l}=C V \\
\mu^{3}\end{array}$ & $\begin{array}{l}=C H \\
p g\end{array}$ & $\begin{array}{l}=C H C \\
\%\end{array}$ & $\begin{array}{l}\text { Ret. } \\
\%\end{array}$ & $\begin{array}{l}\text { Glutathione } \\
\text { mg GSHI } \\
100 \mathrm{ml} \\
\text { cells }\end{array}$ & $\begin{array}{l}\text { Glutathione } \\
\text { reductose } \\
I U / g \mathrm{Hb}\end{array}$ & $\begin{array}{l}\text { Glutathione } \\
\text { peroxidase } \\
\mathrm{IU} / \mathrm{g} \mathrm{Hb}\end{array}$ & $\begin{array}{l}G 6 P D \\
I U / g \\
H b\end{array}$ & $\begin{array}{l}\text { 6PGD } \\
I U / g \\
H b\end{array}$ \\
\hline $\begin{array}{ll}\text { I.1 } & 50 \\
\text { I. } 2 & 45 \\
\text { II.1 } & 30 \\
\text { II. } 2 & 18 \\
\text { II.3 } & 6 \\
\text { II.4 } & 20 \\
\text { II.5 } & 23 \\
\text { II. } 6 & 26 \\
\text { II.7 } & 27\end{array}$ & $\begin{array}{l}\text { A/PA } \\
\text { AA } \\
\text { A/PA } \\
\text { AA } \\
\text { A/PA } \\
\text { A/PA } \\
\text { AA } \\
\text { A/PA } \\
\text { A/PA }\end{array}$ & $\begin{array}{l}14.3 \\
13.6 \\
12.6 \\
14.5 \\
14.5 \\
13.2 \\
14.1 \\
15.6 \\
14.7\end{array}$ & $\begin{array}{l}4.86 \\
4.73 \\
4.16 \\
4.87 \\
4.43 \\
4.78 \\
4.82 \\
4.95 \\
4.61\end{array}$ & $\begin{array}{l}43 \\
38 \\
36 \\
43 \\
42 \\
40 \\
43 \\
46 \\
40\end{array}$ & $\begin{array}{l}90 \\
81 \\
86 \\
90 \\
93 \\
85 \\
91 \\
96 \\
87\end{array}$ & $\begin{array}{l}36 \\
27 \\
30 \\
30 \\
31 \\
28 \\
30 \\
33 \\
32\end{array}$ & $\begin{array}{l}34 \\
34 \\
36 \\
34 \\
34 \\
34 \\
34 \\
34 \\
37\end{array}$ & $\begin{array}{l}1.0 \\
1.5 \\
1.1 \\
1.8 \\
1.0 \\
0.8 \\
0.9 \\
1.0 \\
1.3\end{array}$ & $\begin{array}{l}57 \\
17 \\
46 \\
19 \\
56 \\
42 \\
26 \\
51 \\
48\end{array}$ & $\begin{array}{l}3.55 \\
2.01 \\
2.64 \\
3.40 \\
3.10 \\
3.91 \\
2.80 \\
2.65 \\
3.00\end{array}$ & $\begin{array}{l}3.06 \\
3.28 \\
3.63 \\
3.78 \\
3.50 \\
5.18 \\
2.90 \\
4.06 \\
4.01\end{array}$ & $\begin{array}{l}7.85 \\
5.80 \\
6.00 \\
4.85 \\
7.00 \\
6.95 \\
4.56 \\
6.94 \\
7.40\end{array}$ & $\begin{array}{l}4.76 \\
4.50 \\
3.95 \\
6.00 \\
5.84 \\
6.30 \\
4.84 \\
5.60 \\
4.30\end{array}$ \\
\hline
\end{tabular}

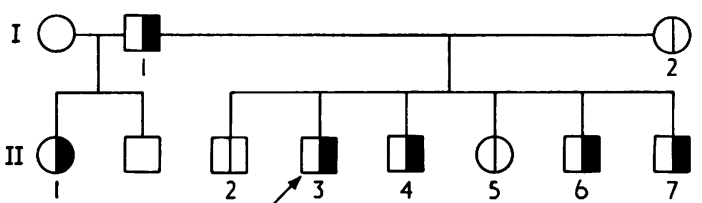

Normal $\square$ Heterozygous for $\mathrm{Hb}$ Porto Alegre $\square$ Not studied

Fig. 1 Family pedigree. The arrow indicates the propositus.

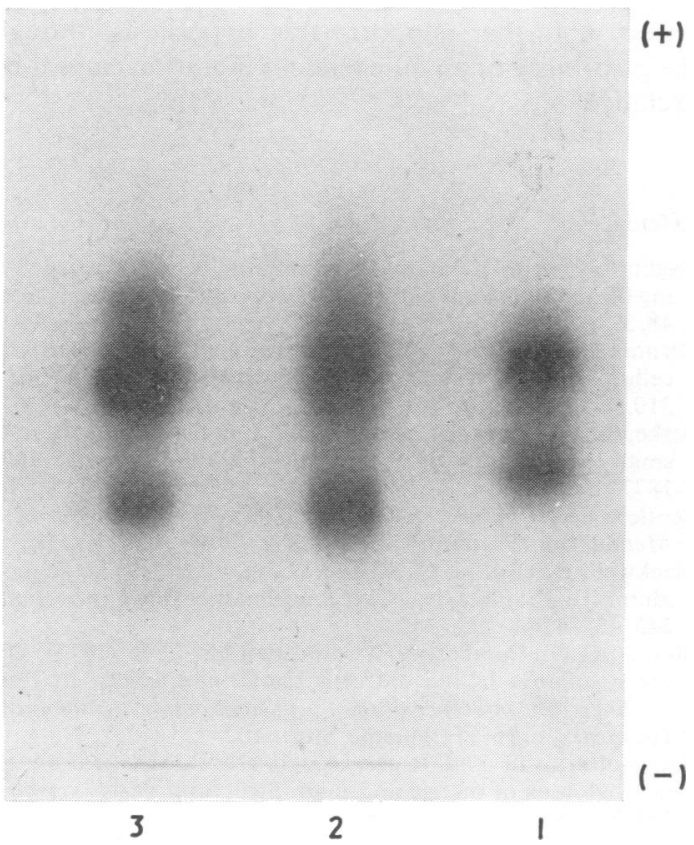

Fig. 2 Electrophoresis of the carrier of $\mathrm{Hb}$ Porto Alegre at $\mathrm{pH} 8 \cdot 6$. (1) HbS heterozygote; (2) and (3) propositus.

Its amount increased with time and its appearance could be prevented by addition of dithyothreitol to a freshly prepared haemolysate. This behaviour suggested that a spontaneous polymerisation caused by the formation of S-S bridges takes place in the haemolysate. The presence of such a polymer was confirmed by gel filtration on Sephacex G-100 and by ultracentrifugation. In both cases a molecular weight consistent with the presence of a haemoglobin octamer was obtained.

The abnormal haemoglobin was purified from a 25-day old haemolysate on a Sephadex G-100 column and on a DEAE-Sephadex column using a $p \mathrm{H}$ gradient: under this last condition the abnormal haemoglobin is eluted after $\mathrm{HbA}$. The amount of the variant was found to be $37 \%$.

It has been reported (Rucknagel et al., 1964) that the $\beta_{2}$ tryptic peptide is absent in the fingerprint of the $\mathrm{Hb}$ Porto Alegre. In our case this peptide could not be located with ninhydrin staining, but after aminoethylation an abnormal peptide appeared in the position shown in Fig. 3. The composition of this peptide is given in Table 2. The abnormal haemoglobin was thus identified as $\mathrm{Hb}$ Porto Alegre $\left(\alpha_{2} \beta_{2}\right.$ $9 \mathrm{Ser} \rightarrow$ Cys).

\section{Discussion}

Haemoglobin Porto Alegre is a clinical and electrophoretic silent mutant. Another variant behaving in the same way has been reported, $\mathrm{Hb} \mathrm{Ta}-\mathrm{Li}$, another $\beta$-chain variant in which the presence of a cysteine in position 83 produces polymerisation on the haemoglobin in the haemolysates (Blackwell et al., 1971). In

Table 2 Amino acid composition of abnormal $\beta$-II peptide

\begin{tabular}{llc}
\hline Amino acid & $\begin{array}{l}\beta_{2} \text { Residues } \\
\text { expected }\end{array}$ & $\begin{array}{l}\beta_{2} \text { Residues } \\
\text { observed }\end{array}$ \\
\hline Thr & 1 & 0.95 \\
Ser & 1 & - \\
Gly & 1 & 1.05 \\
Ala & 2 & 2.08 \\
Val & 1 & 1.21 \\
Leu & 1 & 0.97 \\
Lys & 1 & 0.98 \\
S-Ae-Cys & 0 & 0.94 \\
Trp & 1 & $*$ \\
\hline
\end{tabular}

* The peptide stained positively for tryptophane. 


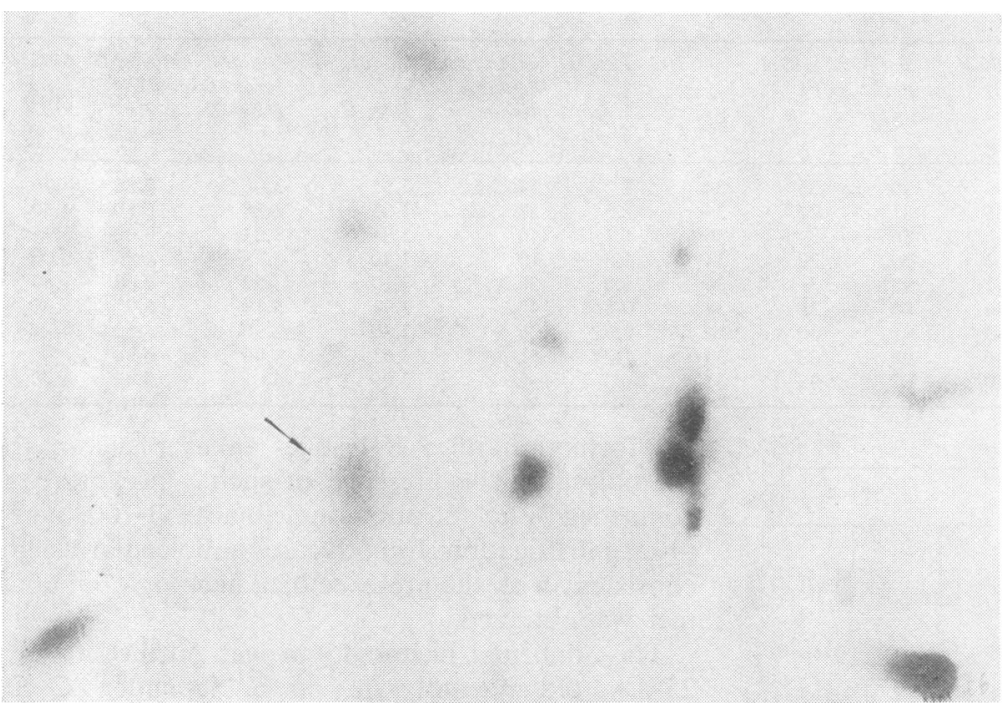

Fig. 3 Fingerprint of aminoethylated $\beta$-chain of $\mathrm{Hb}$ Porto Alegre. The arrow indicates the abnormal peptide. both cases there are no pathological consequences and no haematological abnormalities, probably because both variants are kept in the normal tetrameric form in the erythrocytes. It would be interesting to know whether cells carrying $\mathrm{Hb}$ Porto Alegre require a special metabolism to maintain the extra thiol groups of the variant in the reduced form: our results indicate that these cells contain higher amounts of glutathione (Table 1). In fact, glutathione levels are twice those of a normal subject, which seems to correspond to the twofold increase of $-\mathrm{SH}$ groups (4 in $\mathrm{Hb}$ Porto Alegre compared to 2 in $\mathrm{HbA}$ ). Glutathione peroxidase and reductase, as well as G6PD and 6PGD activities were found to be normal (Table 1).

It is believed that at least one of the functions of glutathione is to protect haemoglobin as well as other thiol containing proteins from denaturation under oxidative stress (Srivastava and Beutler, 1970). Independently of the different mechanism proposed to explain this function (Blume et al., 1973), our findings suggest that higher levels of glutathione are needed in the presence of unusually high number of -SH groups. Thus it seems reasonable to propose that the increased levels of glutathione in the red cells of $\mathrm{Hb}$ Porto Alegre carriers is the result of the need to maintain the abnormal haemoglobin in the tetrameric functional form, though the biochemical mechanism responsible for this high concentration is not clear. Experiments are under way to clarify this point.

To explain the findings of 3 probably unrelated cases of $\mathrm{Hb}$ Porto Alegre, 2 in Brazil and 1 in Argentina, it has been suggested that the gene responsible for this variant could be relatively common in Portu $\vec{\square}$ gal and in Spain (Seid-Akhaven et al., 1973). The finding of a new case in a Cuban family of Spanish ancestry, further supports this hypothesis, though the possibility of an independent mutation cannot be excluded.

\section{References}

Baglioni, C. (1961). An improved method for the fingerprint ing of human haemoglobins. Biochimica et Biophysica Acta? 48, 392-396.

Bernini, L. F. (1969). Rapid determination of $\mathrm{HbA}_{2}$ by DEAEcellulose chromatography. Biochemical Genetics, 2, 305310.

Betke, K., Marti, H. R., and Schlicht, I. (1959). Estimation of? small percentages of foetal haemoglobin. Nature, 187,0 1877-1878.

Beutler, E. B. (1968). Hereditary Disorders of Erythrocyte Metabolism. Grune and Stratton, New York.

Blackwell, R. Q., Liu, C. S., and Wang, C. L. (1971). Hemo-음 globin Ta-Li: $\beta 83$ Gly $\rightarrow$ Cys. Biochimica et Biophysica Acta 243, 467-474.

Blume, K. G., Paniker, N. V., and Beutler, E. B. (1973). On the regulation of the red cells glutathione levels. In Proceedings 16 Conference of the European Society of Biological? Chemistry, p. 157, F. Thieme, Stuttgart.

Bonaventura, J., and Riggs, A. (1967). Polymerization of hemoglobins of mouse and man. Structural basis. Science, 158, 800-802.

Clegg, J. B., Naughton, M. A., and Weatherall, D. J. (1966). Abnormal human haemoglobins. Separation and charac- $N$ terization of the $\alpha$-and $\beta$-chains by chromatography and theN determination of two new variants: Hb Cheasepeake and $\omega$ HbJ Bangkok. Journal of Molecular Biology, 19,91-108.

Dacie, J. V., and Lewis, S. M. (1966). Practical Haematology 3rd ed. Churchill, London.

Heredero, L., Granda, H., Suárez, J. A., and Altland, K. (1974). An economic high speed electrophoretic screening- 
system for hemoglobin $\mathrm{S}$ and other proteins. Humangenetik, 21, 167-177.

Jonxis, J. H. P., and Huisman, T. H. A. (1968). A Laboratory Manual on Abnormal Haemoglobins, 2nd ed. Blackwell, Oxford.

Peñalver, J. A., and de Miani, M. S. A. (1972). Hemoglobinopathies in Argentina. In Abstracts 14th International Congress of Hematology, p. 407.

Peñalver, J. A., de Miani, M. S. A., Lang, A., and Lehmann, H. (1971). Hb Porto Alegre y asociación Hb Porto Alegre $\beta$-talasemia. Medicina (Madrid), 31, 493.

Rucknagel, D. L., Tondo, C. V., and Salzano, F. M. (1964). Hemoglobin Porto Alegre, a possible polymer of normal hemoglobin. In Proceedings of the 9th Congress of the International Society of Hematology, Vol. III, p. 29.

Seid-Akhaven, M., Ayres, M., Salzano, F. M., Winter, W. P., and Rucknagel, D. L. (1973). Two more examples of Hb Porto Alegre in Belén, Brazil. Human Heredity, 23, 175-181.

Smithies, O. (1959). An improved procedure for starch-gel electrophoresis: further variations in the serum of normal individuals. Biochemical Journal, 71, 585-687.
Srivastava, S. K., and Beutler, E. B. (1970). Glutathione metabolism of the erythrocyte. Biochemical Journal, 119, 353-357.

Tondo, C. (1972). Hemoglobin Porto Alegre: an asymmetric tetramer with only one abnormal beta chain in the aged hemolyzate of erythrocytes from the heterozygous carrier. Anales Academia Brazileira de Ciencias, 44, 337-347.

Tondo, C., Salzano, F. M., and Rucknagel, D. I.. (1963). Hemoglobin Porto Alegre a possible polymer of normal hemoglobin in a Caucasian family in Brazil. American Journal of Human Genetics, 15, 265-279.

WHO (1967). Standardisation of procedures for study of glucose-6-phosphate dehydrogenase. Technical Report Series, 366. Geneva.

Yunis, J. J. (1969). Biochemical Methods in Red Cell Genetics. Academic Press, New York and London.

Requests for reprints to Dr B. Colombo, Instituto de Hematología e Inmunologia, Hospital E. Cabrera, Apartado 8070, Altahabana, La Habana 8, Cuba. 